2019-12-01

\title{
William King, Sir William Petty, and Post-War Ireland (169092): Sir Robert Southwell and the Printing of Political Discourse
}

Hinds, Peter

http://hdl.handle.net/10026.1/11650

10.1093/library/20.4.475

The Library

Oxford University Press (OUP)

All content in PEARL is protected by copyright law. Author manuscripts are made available in accordance with publisher policies. Please cite only the published version using the details provided on the item record or document. In the absence of an open licence (e.g. Creative Commons), permissions for further reuse of content should be sought from the publisher or author. 
'William King, Sir William Petty and Post-War Ireland (1690-92): Sir Robert Southwell and the Printing of Political Discourse'

\begin{abstract}
This article analyses the production of printed political discourse between post-war Ireland and England, in particular Sir Robert Southwell's leading role in bringing to publication William King's The State of the Protestants and Sir William Petty's The Political Anatomy of Ireland in 1691. The questions these two books raised for the settlement of Ireland and for the relationship between the two kingdoms of Ireland and England have become very important for Anglo-Irish political history yet their publication circumstances in 1691 have not been considered. The article argues that studying these circumstances, applying the methods of book history, and analysing carefully reception contexts reveals the ways that senior government figures used print for political and personal influence, demonstrates the growing role and sophistication of printed discourse in Anglo-Irish politics, and uncovers how networks of trusted friends and allies operating between kingdoms could be crucial for the production and favourable reception of political argument in print. These two detailed case studies offer new directions for thinking about precisely how and by whom political discourse was generated, how it circulated, and how it was received and understood in turbulent times, with church government, the constitutional relationship between kingdoms, and personal interests in flux and facing an uncertain future, towards the end of James II's Ireland campaign.
\end{abstract}




\section{Introduction}

This article examines the production of printed political discourse in Ireland and London following the defeat of James II's Irish campaign in 1691. Post-war uncertainties over the nature of the settlement for Ireland in church and state, but also for individual property and interests, generated anxious and often hostile exchanges that have stimulated significant scholarly debate in recent years. Matters of Protestant Anglo-Irish identity formation, the nature of the relationship between the two kingdoms - particularly the idea of union - and the contentious issues of allegiance and passive obedience around the change of monarch, all formed part of the post-war political landscape. ${ }^{1}$ The idea of union especially (in which there is still something at

\footnotetext{
${ }^{1}$ Jim Smyth overviews the nature of Protestant anxiety for the future of Ireland in 'The Communities of Ireland and the British State, 1660-1707', in The British Problem, c. 1534-1707: State Formation in the Atlantic Archipelago (Basingstoke: Palgrave Macmillan, 1996), ed. by Brendan Bradshaw and John Morrill, pp. 246-61. For identity formation and union in the late seventeenth century see T. C. Barnard,
} 'Crises of Identity among Irish Protestants 1641-1685', Past \& Present, 127 (1990), 39-83, James Kelly, 'The Origins of the Act of Union: An Examination of Unionist Opinion in Britain and Ireland, 1650-1800', Irish Historical Studies, 25 (1987), 236-63, Jim Smyth 'Like Amphibious Animals': Irish Protestants, Ancient Britons, 1691-1707', The Historical Journal, 36 (1993), 785-97, chapters by Robert Eccleshall, D. George Boyce, James Kelly and David Hayton in Political Discourse in Seventeenth-and Eighteenth-Century Ireland (Basingstoke: Palgrave, 2001), ed. by D. George Boyce, Robert Eccleshall, and Vincent Geoghegan, particularly Hayton's, 'Ideas of Union in Anglo-Irish Political Discourse, 1692-1720: Meaning and Use’, pp. 142-64. See also Hayton’s ‘Anglo-Irish Attitudes: Shifting perceptions of national identity', in his The Anglo-Irish Experience: Religion, Identity and Patriotism (Woodbridge, The Boydell Press, 2012), pp. 25-48, and Charles Ivar Mcgrath, 'English Ministers, Irish Politicians and the Making of a Parliamentary Settlement in Ireland, 1692-5', English Historical Review, 119 (2004), 585-613, 'Government, Parliament and the Constitution: The Reinterpretation of Poynings' Law, 1692-1714', Irish Historical Studies, 35 (2006), 160-72, and in 
stake for the historiography of Ireland) and the assumptions made about the nature and extent of unionist sentiment expressed in relation to Ireland post-1691, have come under recent pressure. David Hayton has done much to clarify this field of argument, pointing out that,

What has been missing from much of the discussion of these texts [that advocate union] has been an exposition of context. The actual weight attached to union by those who raised the issue; the degree to which such would-be opinion-formers were, or were not, representative of the Irish 'political nation'; above all, whether a handful of pamphlets, several parliamentary addresses, and the occasional flourish in private correspondence, can properly be said to constitute a discourse. ${ }^{2}$

This is a good methodological point, though this article will argue that bringing to bear the context of print culture and the methods of book production helps re-frame what constitutes that discourse and demonstrate the subtleties of its operation. ${ }^{3}$

\footnotetext{
'The 'Union' Representation of 1703 in the Irish House of Commons: A case of mistaken identity?', Eighteenth-Century Ireland/Iris an dá chultúr, 23 (2008), 11-35. See also Jane Ohlmeyer, 'Seventeenth-Century Ireland and the New British and Atlantic Histories', The American Historical Review, 104 (1999), 446-62, and essays in Political Though in Seventeenth-Century Ireland: Kingdom or Colony (Cambridge: Cambridge University Press, 2000), ed. by Jane Ohlmeyer.

${ }^{2}$ Hayton, 'Ideas of Union in Anglo-Irish Political Discourse', in Political Discourse, ed. by Boyce, Eccleshall, and Geoghegan, p. 146. Charles Ivar Mcgrath also questions the importance of unionist sentiment in “'The 'Union' Representation of 1703', pp. 31-32.

${ }^{3}$ For the history of the book in early modern Ireland see Raymond Gillespie's Reading Ireland: Print, Reading and Social Change in Early Modern Ireland (Manchester: Manchester University Press, 2005)
} 
The focus will be on two books, both printed in 1691, that attempted to influence the post-war settlement debate, William King's The State of the Protestants in Ireland and Sir William Petty's The Political Anatomy of Ireland. Whilst the books' ideas have become important to the political historiography of late seventeenth- and eighteenth-century Ireland - in that they engage with precisely those issues of Protestant Anglo-Irish identity, union and the relationship between kingdoms, and political allegiance - their publication and reception contexts have never been explored. Examining them in the light of these contexts challenges current assumptions about how they contributed to Anglo-Irish politics and the legacy they left. They are what might be called 'inter-kingdom' publications, produced between Ireland and England, with complex political agendas delivered into unpredictable reception contexts. ${ }^{4}$ These detailed case studies highlight the many complexities, sensitivities, and multiple agents that need accounting for when attempting to determine the intentions, meanings, and effects of Anglo-Irish political discourse.

The article has three strands. Firstly, it argues that the means by which particular political views regarding Ireland's future found printed expression in London depended upon networks of friendship and influence operating across the Irish Sea. Editors, booksellers, and other representatives corresponding between

and The Oxford History of the Irish Book, Volume III: The Irish Book in English, 1550-1800 (Oxford: Oxford University Press, 2006), ed. by Gillespie and Andrew Hadfield.

${ }^{4}$ Tim Harris has written about the writing of Irish history from 'insular' (Irish) and 'externalist' (English/British) positions: 'Restoration Ireland - Themes and Approaches', in Restoration Ireland: Always Settling and Never Settled (Ashgate: Aldershot, 2008), ed. by Coleman A. Dennehy, pp. 1-17 (5-9). The study of the circumstances of these two books' publication, William King's in particular, can help bridge these two positions. 
Ireland and London - in particular the diplomat Sir Robert Southwell, the bookseller Robert Clavell, and the lawyer George Tollet - had influential roles in producing the printed books that sought to shape Ireland's future. King's The State of the Protestants demonstrates how friendships - founded on trust, dependency and obligation - were necessary in many ways: for managing the book's publication through several editions; negotiating King's precarious pre- and post-war personal circumstances; maintaining his personal reputation; arguing with authority and credibility in print for a particular political and church settlement in Ireland; for framing the narrative of the recent Irish past, as well as providing support and encouragement for this isolated Bishop writing from Derry on delicate and controversial matters. ${ }^{5}$ The correspondence deliberations over the writing, production, and reception of King's The State of the Protestants show an extraordinary level of trust on the part of King, and a kind of 'devolved authorship' amongst his London friends and allies. ${ }^{6}$

Secondly, the article considers the posthumous publication of Sir William Petty's The Political Anatomy of Ireland in 1691 (Petty died on 19 December 1687). The Political Anatomy, as well as the 1690 printed edition of his Political Arithmetick, has been at the centre of a recent revisionist re-appraisal of Petty, which places greater

\footnotetext{
${ }^{5}$ See Cedric Brown's Friendship and its Discourses in the Seventeenth Century (Oxford: Oxford University Press, 2016) for a subtle and finely-discriminating examination of these kinds of relationship.

${ }^{6}$ Raymond Gillespie looks at how King engaged in printed political controversy in relation to King's $A$ Discourse concerning the Inventions of Men in the Worship of God (1694); 'Irish print and Protestant identity: William King's pamphlet wars, 1687-1697', in Colonial and Confessional Mentalities in Early Modern Ireland: Essays in Honour of Karl S. Bottingheimer (Dublin: Four Courts Press, 2003), ed. by Vincent P. Carey and Ute Lotz-Heumann, pp. 231-50.
} 
emphasis on the contemporary manuscript circulation of his work in his lifetime rather than the selected works that found their way into print, particularly those that did so posthumously. ${ }^{7}$ This re-appraisal calls into question the figure of Petty that emerged from the mid-nineteenth century - as the founder of a modern statistical economics, macroeconomic theory, or social science - and has produced important new readings of Petty's work from the manuscript archives made publicly available in January $1993 .^{8}$ This part of the article argues that the distinction between the manuscript archive and the printed editions has been drawn too sharply and that Petty played a part in securing his posthumous, printed legacy, encouraged and brokered by

\footnotetext{
${ }^{7}$ This was initiated by Tony Aspromourgos; see 'New Light on the Economics of William Petty (16231687): Some Findings from previously undisclosed Manuscripts', Contributions to Political Economy, 19 (2000), 53-70, and 'The invention of the concept of social surplus: Petty in the Hartlib Circle',
} European Journal of Economic Thought, 12 (2005), 1-24.

${ }^{8}$ These papers are in the British Library (London, British Library, Add MS 72850-72908: 1646-1698, 'Correspondence and Papers of Sir William Petty (1623-1687)'). Ted McCormick has sought to correct misinterpretations of Petty's ideas from the 1690s onwards; see 'Alchemy in the political arithmetic of Sir William Petty (1623-1687)', Studies in the History of Political Science, 37 (2006), 290-307, 'Transmutation, Inclusion, and Exclusion: Political Arithmetic from Charles II to William III', Journal of Historical Sociology, 20 (2007), 259-78, “ 'A Proportionable Mixture’: William Petty, Political Arithmetic, and the Transmutation of the Irish', in Restoration Ireland, ed. by Dennehy, pp. 123-39, and William Petty and the Ambitions of Political Arithmetic (Oxford: Oxford University Press, 2009). Hugh Goodacre has also made revisionist interventions; in particular see 'Technological progress and economic analysis from Petty to Smith', European Journal of Economic Thought, 17 (2010), 11491168 and 'The William Petty problem and the Whig history of economics', Cambridge Journal of Economics, 38 (2014), 563-583. See also Adam Fox, 'Sir William Petty, Ireland, and the Making of a Political Economist, 1653-87’, The Economic History Review, New Series, 62 (2009), 388-404. 
his great friend and cousin, Sir Robert Southwell. ${ }^{9}$ Southwell had The Political Anatomy published in 1691 in the midst of the post-war Ireland debates over political and legislative union and land settlement (that had underpinned so much of Petty's writing about Ireland), employing as editor the Irish émigré and future Poet Laureate, Nahum Tate. The publication context has been left unexplored but, with this context in view, the 1691 printed edition of The Political Anatomy looks less like the first step on the road to a distorted posthumous legacy, but rather an attempt to put Petty's ideas to political use by a close friend and relative in relation to Ireland.

The third aspect of the article is Sir Robert Southwell himself, and it considers his efforts to influence political discourse through print in the late seventeenth century. His friendships with William King and Sir William Petty, and his activities in the book trade in London, were crucial for his attempts to shape Irish political matters generally, and also look after his own Irish interests, remotely, from England. He was born near Kinsale in 1635 where the Southwell family had accumulated land and property including part of the docks, which generated an estimated annual income of $£ 1000 .{ }^{10}$ Southwell was an absentee from Ireland for much of his life, but his Kinsale property - particularly its use as a port, given its location for shipping - shaped his attitude towards union between Ireland and England and the nature of trade between the two kingdoms, especially at a time when the Anglo-Irish constitutional framework had been shaken and anxieties over the Restoration political and land settlement re-

\footnotetext{
${ }^{9}$ Tony Aspromourgos expresses reservations about the division drawn between Petty's lifetime and the legacy: Aspromourgos, Irish Historical Studies, 37 (2010), 130-31.

${ }^{10}$ Toby Barnard, A New Anatomy of Ireland: The Irish Protestants, 1649-1770 (New Haven and London: Yale University Press, 2003), p. 148, and 'Sir Robert Southwell', in Oxford Dictionary of National Biography (Oxford: Oxford University Press, 2004), 60 vols, 51, pp. 718-21 (721).
} 
surfaced. ${ }^{11}$ Southwell's book-trade activity and interest in union and property offer new contexts for King's The State of the Protestants and Petty's The Political Anatomy and revise the understanding of how King's political views were understood in relation to Ireland (given his later patriotism). They move the debate over union in a different direction, offering another view of how unionist discourse might have operated. Southwell made consistently energetic and influential contributions to political and intellectual life in the late seventeenth century and was an extensive correspondent yet he awaits a biographical study. ${ }^{12} \mathrm{He}$ is representative of wider Protestant anxieties at this time, and if the 'Protestant Ascendancy' came to seem inevitable in hindsight, his activities tap us into the deeply felt fears of many Protestants for the future of Ireland and their own interests there. ${ }^{13}$ Tracing his friendships, correspondence, and his activities in the book trade reveals much about the production of political discourse in relation to Ireland and the late seventeenth century more generally.

At root this argument is methodological, seeking to complicate ideas of 'authorship' and 'authority' in relation to the writing and publication of books

\footnotetext{
${ }^{11}$ Barnard, A New Anatomy, p. 148

${ }^{12}$ Gibney has attributed, edited and annotated a document from Southwell to his son, '[Sir Robert Southwell] 'Some Remarks on those who were Friends and Enemyes to the Duke of Ormonde and to the Acts of Settlement of Ireland' [c. 1692]', Analecta Hibernica, 42 (2011), 25-58. Helen Jacobsen considers Southwell in the context of European diplomacy, Luxury and Power: The Material World of the Stuart Diplomat, 1660-1714 (Oxford: Oxford University Press, 2012). Peter Hinds in 'The Horrid Popish Plot': Roger L'Estrange and the Circulation of Political Discourse in Late-SeventeenthCentury London (London: The British Academy and Oxford University Press, 2010), examines Privy Council work and correspondence with Ormond during the Popish Plot.

${ }^{13}$ On these anxieties see Smyth, 'The Communities of Ireland', pp. 257-61.
} 
between Ireland and England at this politically unstable moment. It takes account of the multiple agents involved in publishing The State of the Protestants and The Political Anatomy, problematizing the singular intentions frequently assumed in political discourse. It also examines assumptions about the legitimacy (and, again, 'authority') of posthumous printed works and questions the binary distinction often made between the cultures of manuscript and print that can obscure how books circulated amongst different groups of readers. Applying the methods of book and reading history to the print debates of post-war Ireland helps define more clearly the nature of political discourse, the ways in which it was produced, and the effects it was calculated to have.

\section{Geographical Distance: Printing William King's The State of the Protestants in Ireland (1691) in London}

William King was Dean of St Patrick's cathedral in Dublin when James began his military campaign in Ireland, and his difficult decision to remain in ecclesiastical office in Ireland during the Jacobite wars of 1689-1691 caused much controversy, which he tried to deal with at length in The State of the Protestants. His adherence to principles of passive obedience and non-resistance to James II and then his subsequent switch of allegiance to William III upon his victory (after which he was made Bishop of Derry, in December 1690) came under hostile scrutiny. ${ }^{14}$ King's

\footnotetext{
${ }^{14}$ For King see Philip O’Regan, Archbishop William King of Dublin (1650-1729) and the Constitution in Church and State (Dublin: Four Courts Press, 2000), Christopher Fauske, William King: A Political Biography (London: Pickering and Chatto, 2011), Archbishop William King and the Anglican Irish Context, 1688-1729 (Four Courts Press, Dublin, 2004), ed. by Christopher Fauske, Joseph Richardson,
} 
choices and the constitutional issues they exemplified for church and state have provided rich material for political historians, yet whilst his The State of the

Protestants has been at the heart of these discussions and its argument subject to detailed analysis, the book's publication circumstances have not been given any consideration. These circumstances offer significant insights into King's political ideas, their circulation, their reception and, more broadly, the complexity of political argument over Ireland at this time.

Sir Robert Southwell proved to be a key ally and friend for King both during the war and in the post-war period. He was made Principle Secretary of Ireland by William III in May 1690, and accompanied him there between June and October of the same year. It was in October, in Dublin, that King first met and made an impression on Southwell. King gave a thanksgiving sermon in St Patrick's cathedral for William III, and after their meeting Southwell would refer to him as 'an excellent man a great sufferer' for his time during the Jacobite wars who had 'preached much to the purpose'. ${ }^{15}$ They would go on to become correspondents between Derry and London. ${ }^{16}$

It was an alliance forged from anxiety, based on both principle and selfpreservation. In July and August 1690 King's contact and network builder in London,

\footnotetext{
‘Archbishop William King (1650-1729): 'Church Tory and State Whig'?', Eighteenth-Century Ireland/Iris an dá chultúr, 15 (2000), 54-76, and Andrew Carpenter, 'William King and the Threats to the Church of Ireland during the Reign of James II', Irish Historical Studies, 18 (1972), 22-28.

${ }^{15}$ Southwell to Daniel Finch, Lord Chancellor and Earl of Nottingham, cited in O'Regan, Archbishop William King, p. 33

${ }^{16}$ The letters are preserved in the King correspondence held at Dublin, Trinity College Library (TCL), MS 1995-2008, letters 131-260.
} 
the lawyer George Tollet, was sending advice to King about whom he considered trustworthy, advising through which channels access to powerful allies might be found, and repeatedly advocating seeking Southwell's support. 'I am sure your own merit will be your best advocate,' he told King 'Nevertheless I recommend you to $\mathrm{S}$. $\mathrm{Ro}^{\text {bt }}$. Southwell by $\mathrm{Ca}^{\mathrm{pt}}[\mathrm{James}]$ Wallers means and I will frequently visit old $\mathrm{S}^{\mathrm{t}}$ Asaph [William Lloyd, Bishop of Asaph] to get the Q[ueen]'s assistance.' ${ }^{17}$ (Tollet would take advantage of William Lloyd's direct connection to the Queen on King's behalf at a later date. ${ }^{18}$ ) Yet only a month later Tollet was no longer convinced that even King's reputation would serve him in London: 'What ever letters I have of yours shall be carefully kept to serve you,' he advised,

but having had some experience of affairs, persons \& intrests in this place [London], I advise you not to depend upon any thing in them nor even to what is most Valluable, your own merit; but serve your self by the best \& surest intrest you can conveniently. [...] And depend not more on [the Bishop of] London [Henry Compton] \& $\mathrm{S}^{\mathrm{t}}$. Asaph than on $\mathrm{S}^{\mathrm{r}}$. Ro ${ }^{\mathrm{bt}}$. Southwell; \& Cap ${ }^{\mathrm{t}}$. Waller is a true and worthy frend, I wish you had my $\mathrm{L}^{\mathrm{d}}$ [Henry] Sidneys ear. $^{19}$

Here Tollet advocated Southwell again as the most dependable ally in a climate of mistrust and uncertainty in London. King was persuaded, and after his meeting with

\footnotetext{
${ }^{17}$ Dublin, TCL, MS 1995-2008, 131-260, Tollet to King, 12 July 1690 (letter 81).

${ }^{18}$ Lloyd would pass to the Queen a copy of King's sermon, Europe's Deliverance from France and Slavery (London: Tim Goodwin, 1691) in February 1692; see below, p. 21.

${ }^{19}$ Dublin, TCL, MS 1995-2008, 131-260, Tollet to King, 11 August 1690 (letter 91).
} 
Southwell in Dublin they became regular correspondents, with Southwell playing a leading role representing King's interests. As soon as November, King sought crucial advice from Southwell (then back in London) on a pressing crisis, Sergeant John Osborne's motion that Protestants who held civil office in Ireland under James II were guilty of high treason. ${ }^{20}$ Feeling under pressure himself, but also defending those who had remained in Ireland and served under James II after April 1689, King sent Southwell a draft of 24 points in response to Osborne that might be used as the basis of a defence. ${ }^{21}$ Osborne's motion caused a considerable initial stir even if it ultimately gained no traction, but the substance of these 24 points forged in urgent response would later become part of the framework for The State of the Protestants. ${ }^{22}$ Southwell was involved at a very early stage in the book's formation.

Tollet warned nervously that 'imploym ${ }^{\text {ts }}$ were never soe uncertain in this world as they are now' suggesting the bookseller Robert Clavell as an ally. Tollet asked King to send sensitive letters for him clandestinely to Clavell's bookshop, marked with the initial G.T. ${ }^{23}$ Clavell would become the publisher of The State of the Protestants and was involved in key decisions regarding its printing. As an integral part of this London network he published other works by King and was and an active producer of (and broker for) Protestant Anglo-Irish political discourse.

\footnotetext{
${ }^{20}$ James McGuire provides a transcription and analysis of these arguments in 'A remora to King James' affairs: William King's defence of protestant office-holders, 1689-90', in Archbishop William King and the Anglican Irish Context, ed. by Fauske, pp. 36-46.

${ }^{21}$ Dublin, TCL, MS 1995-2008, 131-260, King to Southwell, 11 November 1690 (letter 100).

${ }^{22}$ For instance, they structure his concluding remarks; King, The State of the Protestants (London: Robert Clavell, 1691), pp. 233-8.

${ }^{23}$ Dublin, TCL, MS 1995-2008, 131-260, Tollet to King, 20 November 1690 (letter 101a).
} 
Some early draft of The State of the Protestants was being selectively circulated for critical opinion by Tollet in London by December 1690. Tollet first sought Southwell's advice on these manuscript papers and reported back the latter's approval. Tollet then left the papers with William Lloyd (the Bishop of Asaph), whose endorsement King was keen to secure (King stated that he 'woud not proceed without his [Lloyd's] approbation'). Tollet discussed the projected book with Lloyd and then sought the opinion of Henry Compton (the Bishop of London). ${ }^{24}$ There was ecclesiastical consultation and support at a very early stage of writing. In particular, as one of the 'seven bishops' imprisoned for objecting to James II's 'Declaration of Indulgence' (1687), William Lloyd had close experience of matters of loyalty and it is possible that Lloyd's period of hedging in relation the change of king in February 1689 rendered his thoughts important for King when justifying his own struggles with allegiance and, in some eyes, what looked like a tardy and self-serving switch to William III. $^{25}$

Tollet had the full manuscript of the The State of the Protestants by September 1691 and passed it to Southwell, who personally sought out a license for print publication. Southwell informed King that he visited Daniel Finch (Secretary of State and The Earl of Nottingham) who, being personally busy, deputized reading over the manuscript to Edward Stillingfleet (the Bishop of Worcester). Southwell next visited Stillingfleet and discussed the draft with him and his guest, Gilbert Burnet (the Bishop of Salisbury). Stillingfleet was also busy but Burnet offered to read over the manuscript and give his opinion. Burnet gave the work his endorsement, following

\footnotetext{
${ }^{24}$ Ibid., Tollet to King, 13 December 1690 (letter 106).

${ }^{25}$ Michael Mullett, 'William Lloyd', in Oxford Dictionary of National Biography, 34, pp. $167-70$ (16970).
} 
which Southwell went back to Finch who, after looking at some of the manuscript, promised his license. ${ }^{26}$ Finch's imprimatur - 'Let this be Printed. Nottingham. WhiteHall, Octob. 15. 1691' - would appear at the head of the book (which was entered into the Stationers' Register on 16 October). ${ }^{27}$ Other books contributing to the allegiance issue in Ireland did not have this authorizing marker. ${ }^{28}$ Thus Southwell had secured the book's public credibility, kept open a channel for King to an influential field of figures, both temporal and spiritual, and had ensured that the State of the Protestants' argument was aired and discussed at an early stage amongst powerful figures in London.

Later in September Tollet and Southwell oversaw the printing of The State of the Protestants. Southwell kept King informed of progress, writing that

I called [...] upon $\mathrm{M}^{\mathrm{r}}$. Tollet to know how the Press or rather the 4 Presses now Employed went forward, and I perceive the book will be out before the sitting of the Parliament, $\mathrm{w}^{\text {ch }}$ is now put of to the $22^{\text {nd }}$ of next month.

Southwell invested much energy in this publication, but his frequent communications also had a broader social aspect, demonstrating his service and friendship, and also for

\footnotetext{
${ }^{26}$ Dublin, TCL, MS 1995-2008, 131-260, Southwell to King, 8 September 1691 (letter 169).

${ }^{27}$ King, State of the Protestants, no sig., opposite title page; A Transcript of the Registers of the Worshipful Company of Stationers; from 1640-1708 A.D. (London, 1914), 3 vols, 3, p. 393.

${ }^{28}$ See for instance Edward Wetenhall's, The Case of the Irish Protestants in Relation to recognizing or swearing Allegiance to and praying for King William and Queen Mary Stated and Resolved (London: Robert Clavell, 1691). Clavell's role in this further demonstrates his efforts in relation to a particular view of Anglo-Irish politics.
} 
maintaining trust. Southwell kept up King's hopes of success and political influence, predicting that his book would coincide with sitting of the much-prorogued English Parliament of 1691 and providing continual support, here noting that 'My Lord ArchBpp [John Tillotson] \& my Lord of Worcester [Stillingfleet] are very desirous to be Entertained with the reading thereof. ${ }^{, 29}$ The reach of, and positive, encouraging interest in, King's book went to the heart of the English state (with Daniel Finch) and top of the Church of England (with John Tillotson) and, as well as documenting the business of printing, the communication of support for an often beleaguered and anxious King was considerable.

The book met with delays, and the hopes for publication before the 22 October Parliament were not fulfilled. On 17 December Southwell told King news of 'those writings $\mathrm{w}^{\text {ch }}$ I now may call a book, for by $\mathrm{M}^{\mathrm{r}}$. Tollet's last Information there wanted, but 2 or 3 sheets to be printed off', pointing out that 'all men are discoursing how to restore Ireland again to the settlement it had, or to a better. ${ }^{30}$ Despite this delay The State of the Protestants was still pitched into live English debates over Ireland's future; and it was popular. The first, quarto edition was a substantial 55 sheets in length and, whilst the print run is not known, its price would have been around three shillings. ${ }^{31}$ Less than two months later Robert Clavell was planning another edition in the smaller octavo format (29 sheets, at between one shilling and one shilling and six

\footnotetext{
${ }^{29}$ Dublin, TCL, MS 1995-2008, 131-260, Southwell to King, 26 September 1691 (letter 174).

${ }^{30}$ Ibid., Southwell to King, 17 December 1691 (letter 195).

${ }^{31}$ D.F. McKenzie cautions over the variability of print runs. It would be methodologically problematic to make an estimate; McKenzie, 'Printing and Publishing 1557-1700: constraints on the London book trades', The Cambridge History of the Book in Britain, 1557-1695 (Cambridge: Cambridge University Press, 2002), ed. by John Barnard and D.F. McKenzie.
} 
pence), which was published in March 1692 (there would be two further editions that year). ${ }^{32}$

Clavell had initiated this new edition, commissioning a preface independently of King, though he asked for advice from Southwell, who thought it best to send King the preface for his perusal and editing. ${ }^{33}$ The life and nature of this proposed preface which was never actually printed with the book - highlights the collaborative publication effort. It was written by John Vesey (the Archbishop of Tuam), but Southwell thought it overlong and too full of Vesey's own personal case (in contrast to King, Vesey chose to go with his family to England in 1689, a move not without its own real hardships, returning in 1691). Besides, Southwell had also seen, via Tollett, King's own subsequent proposal for a preface; 'I never Read any thing with more delight then the Modell you prescribe,' he wrote in March 1692, 'which Ought in every Title to be fulfilled, to make a Preface as it ought to be, superior to the Book. And if ever any Provocation be given by the Adverse Party, it may be fit to Write, and pursue those Instructions, if we can find the Man. ${ }^{34}$ The fears regarding this 'Adverse Party' and the close attention to a publication strategy based on assumptions about readers' reception and response is quite striking. Producing an appropriate preface was no simple or automatic task. Clavell's commissioned piece by Vesey was, after consultation, rejected, Southwell preferring one whose content was shaped by King's own draft, but then written within this guiding frame by another author in London.

This controversy from the 'Adverse Party' led Southwell and Clavell 'to Leave all new things alone,' until 'they give Provocation, as they Menace, by

\footnotetext{
${ }^{32}$ Fauske, William King, p. 79.

${ }^{33}$ Dublin, TCL, MS 1995-2008, 131-260, Southwell to King, 6 February 1692 (letter 206).

${ }^{34}$ Ibid., Southwell to King, 29 March 1692 (letter 218).
} 
Answering the Book'. ${ }^{35}$ This 'Menace' was stirred by plans for new material proposed by Clavell. The Lord Chief Justice of Ireland, Sir Richard Reynell, had passed some additional letters to him, to be placed in the book's Appendix of documents, providing further support for King's argument of Catholic treachery and evidence for the Catholic clergy's support of James II in Ireland in 1689. The letters' author, Theophilus Butler, an Irishman with political ambitions who did not want to be dragged back into wartime controversy, threatened to traduce King's reputation if they were published. ${ }^{36}$ Butler's threat was heeded and the letters were not included in later editions.

In addition to this, in February 1692, Southwell had picked up some readers' objections to the first edition, informing King that

There is one point in your Lordshpps book and but one that I ever heard of, $\mathrm{w}^{\mathrm{ch}}$ is cavilled at; and that is the ill condition of the English fleet under K. James. so that if it be reprinted as it was, it may deserve a large Marginall note, signifying that altho in fact this of $y^{\mathrm{e}}$ fleet were otherwise, yet was it so discours't by K. James, and perhaps to animate his friends on that side to the easier regaining of England. It is certain that the fleet of England was for a long time in a ruinous condition, but in the 2. last years of K James' Reign there was very great care and expense to reinforce them. ${ }^{37}$

\footnotetext{
${ }^{35}$ Ibid.

${ }^{36}$ Ibid.

${ }^{37}$ Ibid., Southwell to King, 6 February 1692 (letter 206).
} 
Part of King's argument to question James II's legitimacy was that he had 'purposely let the Ships of England decay and rot, that the French might grow great at Sea, and destroy the Trade of the English.' The reason behind this was to 'humble his Subjects, and take away their Wealth from them, that made them proud and surly, so that the King could not have his Will of them'. ${ }^{38}$ James, went King's argument, had sought arbitrarily to weaken his subjects the better to master them.

There was talk between King, Southwell, and Tollet of 'amending that Passage in the State of Ireland which Concerns the Navy', but in subsequent editions the passage was left to stand with Southwell's suggested marginal note duly inserted next to it (probably written by Tollet ${ }^{39}$ ):

The Author living in another Kingdom, and not knowing how much had been expended on the English Navy towards the end of King James's Reign, was led into this Inference by hearing, that the then Prince of Orange found no Opposition at Sea when he came for England. ${ }^{40}$

So, rather than remove the passage, it was contextualized, exculpating King with reference to his limited knowledge of English affairs in Ireland, and his relying upon reports from England. The broader credibility of the book and its claims were

\footnotetext{
${ }^{38}$ King, The State of the Protestants, p. 82.

${ }^{39}$ Certainly not written by King himself and between Southwell and Tollet perhaps the latter is the most likely candidate: ' $\mathrm{M}^{\mathrm{r}}$. Tollet and I had long since agreed upon a Marginall note, which was soone printed off. and I hope it will be to your liking, for we thought best to leave the Originall as it was', Dublin, TCL, MS 1995-2008, 131-260, Southwell to King, 29 March 1692 (letter 218).

${ }^{40}$ King, The State of the Protestants, p. 93.
} 
important to all involved in the enterprise and errors were addressed, as were readers' objections. The London network of Tollet, Southwell, and Clavell paid close attention to these matters of credibility and made sure that the book remained responsive to opinion in ways that its author could not.

Robert Clavell had consistently shown his ongoing engagement with Irish matters. ${ }^{41}$ His bookshop even became a place to which The State of the Protestants' readers were invited to return for evidence. The first item in King's Appendix was 'An Act for the Attainder of Divers Rebels and for preserving the Interest of Loyal Subjects', legislation passed in 1689 that stripped many Protestants of their Irish lands. ${ }^{42}$ In the first edition all the names mentioned in the Act (over 2,000) were listed, taking up approximately 42 quarto pages (or five sheets of paper). In later editions the names were removed, most likely for reasons of cost and bulk (as these names alone made up around $10 \%$ of the entire book). Unusually, probably because this Act was a key piece of evidence against James II and accuracy and credibility were important, a marginal note was inserted where the names had been removed; 'The Names of the Persons Attained by this Act are here omitted; but a List of them may be had singly at Mr. Robert Clavell's Shop' ${ }^{43}$ Clavell's association with this book, and by extension a certain kind of Anglo-Irish discourse more generally, was

\footnotetext{
${ }^{41}$ For example, relevant titles with Clavell's involvement are $A$ True Account of the Whole Proceedings of the Parliament in Ireland (London, 1689) and An Account of the Transactions of the Late King James in Ireland (London, 1690). He extended to anti Irish-Catholic dramatic satire with the second edition of Thomas Shadwell's The Lancashire Witches, and Tegue o Divelly the Irish Priest (London, 1689).

${ }^{42}$ King, State of the Protestants, p. 241-98.

${ }^{43}$ King, State of the Protestants, $2^{\text {nd }}$ edition, p. 272.
} 
strongly signaled for readers, as his shop became a place of resort here, a component of the book's rhetorical architecture.

Whilst The State of the Protestants was King's most important work, the London network was active in other ways too. King's sermon preached in Dublin for William III on 30 November 1690 also became a crucial text in the debates over recent Irish history. This sermon, printed shortly after it was given in both Dublin and London (by Clavell), was reprinted just after The State of the Protestant's first edition by personal request of Henry Sidney under a new title, Europe's Deliverance from France and Slavery. Henry Sidney had been a prominent military commander for William in the Jacobite conflict, who was made one of the Lord Justices of Ireland (September 1690) and appointed Lord Lieutenant in March 1692. King outlined the long history of Catholic treachery in England and Ireland of which James II had been the latest incarnation. He highlighted the providential nature of William's victory over James, a key plank in King's defence of his initial non-resistance and subsequent change of allegiance. God had sent Ireland a deliverer from a tyrant. ${ }^{44}$

Tollet had arranged the London reprint, and he also personally delivered copies to specific individuals, most of whom had interests in Ireland; Henry Sidney, Richard Coote (an Irishman, the Earl of Bellamont, governor of Country Leitrim, and a owner of a significant amount of Irish land), William Lloyd, as well as Southwell. Lloyd went so far as to give his copy to the Queen, and asked for another copy to replace it. (Here the aspiration back in July 1690 to use Lloyd's royal connection bore fruit.) Tollet lent his own copy to friends who wanted to see it, but demand was so high he could not satisfy everyone. Ultimately he arranged to have more copies

\footnotetext{
${ }^{44}$ Over half of the sermon is given over to the theme of deliverance and providence: King, Europe's Deliverance, pp. 13-24.
} 
printed which, as well as allowing Tollet to meet the demand, had the additional benefit, he told King, of

free [ing] $\mathrm{y}^{\mathrm{r}}$ sermon from the Printers faults; I markt $\mathrm{y}^{\mathrm{e}}$ [printed] coppy where $y^{\mathrm{e}}$ Letter shou'd be chang'd; made Great or Small[;] and where the Printer had mispointed \&c; and caus'd a final impression to be printed here, to furnish those whom I have promist to; and one or two send your Ldp as a specimen of our care $\&$ industry in printing: Tho[ugh] the Printers here, $w^{\text {th }}$ out good looking after, are extream negligent $\&$ idle. ${ }^{45}$

Tollet arranged this extra impression, improving the quality and thus maintaining the credibility of the printed sermon (to the point of marking up errata and overseeing the printing himself). The trust between King and his friends was such that the latter felt confident in executing a devolved initiative on the author's behalf, reacting to the traffic of debate in London, and trying to influence opinion in ways that King could not from Derry.

The production and reception of King's works thus relied heavily on the instincts and decisions of his remote London network. Sir Robert Southwell is not usually considered in relation to book publication but his role here was advisory and editorial, making key decision on content and publication strategy, and opening channels of access for King in order to maximize his influence on Anglo-Irish affairs. He was also a supportive, encouraging, and to some degree a self-interested, friend and ally. More broadly, his involvement illustrates the extent to which senior

\footnotetext{
${ }^{45}$ Dublin, TCL, MS 1995-2008, 131-260, Tollet to King, 14 February 1692 (letter 207).
} 
government figures understood the importance, and exploited the workings, of print culture.

Temporal distance: printing Sir William Petty's The Political Anatomy of Ireland (1691) posthumously

Southwell's interests in Ireland, his correspondence with King, and his actions on the latter's behalf provide the context here for the analysis of Sir William Petty's The Political Anatomy of Ireland. Southwell had a close friendship with Petty and a deep admiration for his work. As with King's The State of the Protestants, Southwell was instrumental in bringing The Political Anatomy - first written in 1672 - into print in 1691, four years after Petty's death, coinciding with the debates over Ireland's postwar future. Prompted by events in Ireland and perhaps also by his involvement with King in late 1690, Southwell was preparing The Political Anatomy for publication in the early months of 1691, as the book received its license on 11 May and was ready for the press by this time. The imprimatur reads 'LICENSED, May the 11th. 1691.' and it was entered in the Stationers' Register on 19 May. ${ }^{46}$ Whether Southwell personally sought out the license is not known, but given the book's political aims and his help with King's The State of the Protestants, it is possible.

However, The Political Anatomy of 1691 also has a longer and more contentious legacy, as it became a significant publication in the history of economic thought and social science, a legacy that has been the subject of recent revisionist scholarship. In his Capital Karl Marx referred to Petty as the 'father of political

\footnotetext{
${ }^{46}$ Petty, The Political Anatomy, A8 ${ }^{\mathrm{v}}$; Transcript of the Registers, 3, p. 386.
} 
economy'. ${ }^{47}$ Marx was dependent on the printed books available to him and he quoted from the 1691, printed edition of Petty's The Political Anatomy to demonstrate his point about paternity. ${ }^{48}$ The scientific figure of Petty generated in the nineteenth century, by Marx and others, and the history of 'political arithmetic' has been challenged and overturned since the late 1990s. What has emerged from scrutiny of Petty's manuscript archive is an ambitious seventeenth-century 'projector' who worked in the service of Cromwell, Charles II, and James II. ${ }^{49}$ Petty's economic thought is no longer regarded as a disinterested, 'scientific' method of calculation but as a political instrument produced locally for powerful patrons in Ireland, and for Stuart monarchs.

Ted McCormick, who makes the strongest case for revision, argues that [Petty's] papers, as he produced them, were designed not so much to reveal scientific or social-scientific truths to the world as to sell economic, political, or social projects to a carefully selected and assiduously pursued audience of powerful men. Political arithmetic, correspondingly, was not set forth wholesale in a treatise, but spun out little by little as a web of projects.

Taking these manuscripts into account does not simply mean supplementing the printed volumes with new material. It requires rereading many of the familiar printed texts as manuscripts, since this was how they circulated, alongside other manuscripts, in Petty's time. This, in turn, means

\footnotetext{
${ }^{47}$ Karl Marx, Capital: A Critique of Political Economy, Volume One (Harmondsworth: Penguin Books Ltd., 1976), p. 384. See McCormick, William Petty, p. 306-11

${ }^{48}$ McCormick, William Petty, p. 309.

${ }^{49}$ See Goodacre, 'The William Petty problem', pp. 572-76.
} 
coming to grips with a new set of problems. Many of the papers were ad hoc responses to the challenges of the moment; while they often address specific problems - ranging from unemployment, to Irish land, to English sovereignty at sea, to church government, to theology and beyond - they rarely enunciate general principles. ${ }^{50}$

In this view, Petty's legacy is a distortion of the initial circumstances and conditions of manuscript publication, circulation, reception, and use, as is the figure of Petty as a founder of modern economic thought and a social scientist. In responding to Charles Henry Hull's two-volume 1899 edition of Petty's work, The Economic Writings of Sir William Petty ${ }^{51}$ ) McCormick goes on to say,

It is not difficult to see in the carefully selected Economic Writings the makings of a proto-scientific approach to economic analysis or to discern precocious anticipations of modern theories. It is much harder to look at hundreds of papers of everything from the shortage of coin to Native American marriage practices to the duties of the parish priest and see the same thing. 52

McCormick is clearly right in an important sense, and his research represents a considerable re-evaluation of Petty's work and thought. However, a significant part of

\footnotetext{
${ }^{50}$ McCormick, William Petty, p. 7

${ }^{51}$ The Economic Writings of Sir William Petty (Oxford: Oxford University Press, 1899), 2 vols, ed. by Charles Henry Hull.

${ }^{52}$ McCormick, William Petty, p. 8.
} 
the history of Petty's ideas and their reception, use and impact, is the subsequent editing and publishing of those ideas, including those printed posthumously. McCormick draws a very sharp line between the initial contexts of Petty's writing, with its manuscript circulation, and the afterlife of that writing in print. Yet this manuscript and print culture separation is not supported by all the evidence. For McCormick, Sir Robert Southwell becomes an 'unofficial archivist' of Petty's work, though his role was more complex and more official as Petty himself, with the insistent prompting of Southwell, began the process of careful selection behind the key posthumous, printed works of the 1690 s. In fact, the printed texts reproduced by Hull and others (rather than the manuscripts), are a continuation of that process of tidying up the disparate manuscript documents produced and circulated over Petty's lifetime. ${ }^{53}$

The correspondence between Petty and Southwell shows an interesting progression in this respect. In 1677 Southwell emphasised how much he valued Petty and his work, referring to an 'Ebony Cabinet wherein I keep, as in an Archive, all the effects of your Pen. ${ }^{54}$ This became a theme of their correspondence: 'I shrine all up,' wrote Southwell in 1682, 'and fancy that in after times I shall be resorted too for your works ${ }^{55}$ Here he represents himself something like McCormick's archivist. It is clear

\footnotetext{
${ }^{53}$ Rhodri Lewis documents some of Southwell's involvement with the manuscript and print circulation of Petty's work in William Petty on the Order of Nature: An Unpublished Manuscript Treatise (Temple: ACMRS, 2012), pp. 10-22.

${ }^{54}$ The Petty-Southwell Correspondence, 1676-1687 (London: Constable and Company, 1928), ed. by the Marquis of Lansdowne, Southwell to Petty, from Spring Gardens, 15 September 1677, p. 34 (letter 20).

${ }^{55}$ Ibid., Southwell to Petty, from Kings Western, 11 September 1682, p. 102 (letter 56).
} 
that the relationship between the two men was close and of deep mutual respect, and Southwell is assiduous in storing Petty's works, yet several years later intimations of Petty's mortality prompt a change in Southwell's attitude and he implores his friend to prepare his papers for publication on many occasions, giving examples of men who did not do so. 'My [...] concerne refers to the Papers you are likely to leave behind you' warned Southwell on 5 October 1687,

and to this I will onely say what I had from our friend $\mathrm{M}^{\mathrm{r}} \mathrm{Ab}[\mathrm{raham}] \mathrm{Hill}$, on occasion of his being left a Trustee to the learned Dr [Isaac] Barrow. He noted that $\mathrm{D}^{\mathrm{r}}$ [Peter] Gunning, a Seraphick man, late Bishop of Ely, had left nothing behind him but a heap of Misticall Scraps, Whereas Dr Barrow scare left one handful of loose papers; soe carefull had he been to finish all he ever tooke in hand, either printing what he wrote, or leaving his thoughts and collections all ready for the Presse. ${ }^{56}$

Petty was alive to these concerns and sent two swift replies: 'As to my papers' he reassured Southwell, 'Those relating to Ireland (and which are neare five hours reading) are correctly ready for any use, and soe are a bundle of others concerning particular designs. The rest I will finish as I can'. ${ }^{57}$ These papers 'relating to Ireland' are almost certainly the fine manuscript of the 'The Political Anatomy', BL Add MS

\footnotetext{
${ }^{56}$ Ibid., Southwell to Petty, from Kings Western, 5 October 1687, pp. 288-9 (letter 176).

${ }^{57}$ Ibid., Petty to Southwell, from Piccadilly, 13 October 1687, p. 293 (letter 178).
} 
21127, Southwell's own copy. ${ }^{58}$ 'You advise me', Petty continued, 'To have my papers ready for the presse. [...] I have many Important papers redy for the presse, and many more Intelligible and usefull perhaps not fit to be printed. Others I perfect daily. ${ }^{59}$ So Petty took Southwell's advice, recognising the importance of print for his legacy and the posthumous impact of his writing. Southwell was not an 'unofficial archivist'; he was more of a general editor engaged to produce authorised editions whom Petty trusted and whose advice he took. Petty was planning for and shaping his reputation beyond death with a literary executor in place. Moreover, McCormick further distinguishes between the "carefully cultivated network of friends, contacts and potential patrons' involved with his writing in manuscript and 'the faceless reading public that would buy Petty's posthumously printed books ${ }^{60}$ Setting coterie, manuscript circulation against 'faceless', public printed circulation establishes another binary which does not quite fit the publication history. We have already seen printed books behaving in ways closer to manuscript circulation in order to achieve influence in relation to William King's work, being used as gifts, and such practices were not unusual. A closer look at the printed book containing 'The Political Anatomy' shows that Southwell shaped it for print with particular ends in mind in pursuit of political influence.

One figure left anonymous in relation to The Political Anatomy is the Irish poet, Nahum Tate. He was chosen to edit the book for print publication and his

\footnotetext{
${ }^{58}$ The Marquis of Lansdowne, the editor of the Petty-Southwell correspondence, surmises that Petty is referring to the 1672 'Political Anatomy' here, which must be a fair scribal copy of the original MS (Petty-Southwell Correspondence, p. 291).

${ }^{59}$ Ibid., Petty to Southwell, from London, October 14 1687, pp. 298-9 (letter 193).

${ }^{60}$ McCormick, William Petty, p. 259.
} 
presence further embeds this book in the Ireland debates of $1691 .{ }^{61}$ No direct evidence survives for Southwell's choice, but Tate's Protestant, Irish identity and his old friendship with William King, dating back to their time at Trinity College Dublin together, are likely reasons.

Tate was born in Dublin in 1652 (he was two years younger than King), entered Trinity College in 1668, and left for London in 1672, supporting himself as a poet, initially in the theatre, but also as a translator, librettist, and editor, becoming Poet Laureate in 1692. His Protestant family were forced from their home in Ballyhaise by the 1641 Irish Catholic uprising, losing property worth thousands of pounds. ${ }^{62}$ Tate's relationship with Ireland and his sense of Anglo-Irish identity was formed by the nation's complex history and relationship with England, by the recent turbulence of national events, but also by his own family history; he represents an example of the complicated identities and interests of the Protestant Anglo-Irish in the late seventeenth century. What scholarship there is on Tate tends to focus on his work in the theatre, primarily his three adaptations of Shakespeare between 1680 and 1682 and his collaboration with Henry Purcell on Dido and Aeneas, but takes little account

\footnotetext{
${ }^{61}$ His involvement is not at all explored in printed editions. The Economic Writings of Sir William Petty, ed. by Hull, uses the 1691 edition as its copy text, collated with extant manuscripts, but does not discuss the publication circumstances and political context of 1691 (I, pp. 122-4). John O'Donovan's facsimile of Tate's 1691 edition does not consider manuscripts or addresses the 1691 publication and political context: The Political Anatomy of Ireland, with the Establishment for that Kingdom and Verbum Sapienti (Shannon: Irish University Press, 1970).

${ }^{62}$ Christopher Spencer, Nahum Tate (New York: Twayne Publisher Inc., 1972), p. 19; David Hopkins 'Nahum Tate', in Oxford Dictionary of National Biography, 54, pp. 811-13 (811). Spencer's short literary biography does not consider his relationship with Ireland.
} 
of his poetry, his work as editor and translator, or his Irish roots. ${ }^{63}$ Scant evidence of Tate's personal views survive, but his entanglements with Ireland, such as The Political Anatomy produced, provide a new context for understanding his writing and political views. Tate became a significant literary figure between his first publication in 1672 and his death in 1715, occupying the role of Poet Laureate from 1692-1714, and preceded more studied literary émigrés from Ireland - William Congreve, Thomas Southerne and George Farquhar - in his move to London. ${ }^{64}$

Tate was in contact with William King in 1691 and wrote to him from London in August, not long after The Political Anatomy's publication, expressing his regret at leaving Dublin, congratulating King on his appointment as Bishop of Derry, and noting that

There has nothing of late been more gratefull to mee than to hear than the Honour our church has receivd by your Lordships Promotion. The distance of Time and the Deluge of Misfortunes that have overwhelmed mee since I left Ireland have not (I can assure you) had the least Power to deface That Respect and Veneration which I conceivd for you upon our first Friendshipp in the Colledge, for to this very minuit I am sensible the same Affection latet arcana non Enarrabile fibra [lying hidden, not able to be spoken, in my secret being].

\footnotetext{
${ }^{63}$ Aside from the Anglo-American literary criticism, there is some Irish scholarship that places Tate in a literary history of Ireland (that will be the topic of another article by this author).

${ }^{64}$ Tate's leading role in the literary migration from Ireland to London has been overshadowed by his later contemporaries and more work is needed on this topic.
} 
Tate identified himself with the Church of Ireland and drew attention to the contrast in their careers and current circumstances. He also told King that his future might lie back in Ireland: 'I have thoughts' he wrote 'upon the Duke of Ormonds return hither from flanders of coming back again to Ireland'. ${ }^{65}$ Whilst Tate did not return to Ireland, remaining in London until his death, he saw an opportunity for patronage in James Butler, the second Duke of Ormond. ${ }^{66}$ Intriguingly, Tate's dedication to The Political Anatomy is to Ormond, and its contents are key to the purpose of this first printed edition. Tate praised Ormond's role in defeating James II in Ireland; Ormond 'had the Honour' he writes 'of accompanying His MAJESTY in an Adventure that shall shine in the Annals of Fame, as long as the Boyne shall maintain its Course' going on to note (with a phrase that anticipated King's popular sermon circulating in London) that he has 'since accompanied our Royal Master to other Shores to be a partaker with him in new Scenes of Action, Undertakings of no less Consequence and Importance, than the Deliverance of Europe. ${ }^{, 67}$ Tate also spoke to the book's topicality, pointing out that 'The usefulness of the ensuing Discourse at this time, when there is so fair a prospect of a new Settlement in IRELAND, were sufficient to recommend it to Your Grace's Protection'. ${ }^{68}$ Given Southwell's close association with the Ormond family and his involvement in James Butler's affairs (Southwell was a

\footnotetext{
${ }^{65}$ Dublin, TCL, MS 1995-2008, 131-260, Nahum Tate to William King, 10 August 1691 (letter 162). The verse is from Perseus' fifth satire.

${ }^{66}$ Ormond represented a good patronage opportunity for someone like Tate; see D. W. Hayton, 'Dependence, clientage and affinity: the political following of the second Duke of Ormonde' in The Dukes of Ormond, 1610-1745, ed. by Toby Barnard and Jane Fenlon (Woodbridge: The Boydell Press, 2000), pp. 211-41.

${ }^{67}$ Petty, Political Anatomy, A3 ${ }^{\mathrm{v}}$.

${ }^{68}$ Ibid., A3 ${ }^{\mathrm{r}}$
} 
friend and correspondent with the first Duke of Ormond and was entrusted as a guardian to his son), it is very possible that Southwell suggested this dedication. There is no record of a connection between Tate and Butler before this, but the coincidence of dates between the letter to William King (August 1691) and his stewardship of The Political Anatomy through the press a few months earlier, hint that Tate's patronage hopes in Ireland may have been generated by this Southwell connection.

Tate's complaints to King demonstrate that he clearly needed the work and would welcome the fleeting contact with an influential figure such as Southwell in 1691. It is implausible that Tate was a random choice; as well as the mutual King connection, his background and his political and religious views were consonant with the circles within which Southwell was circulating The State of the Protestants, as part of the emergent Protestant Anglo-Irish ascendency. The contextual evidence regarding the publication of The Political Anatomy is far patchier than for The State of the Protestants, nevertheless those involved, the timing of publication, and the sentiments expressed in the dedication (and the specific choice of dedicatee) point to an intervention in the post-war settlement debate and the idea of union between England and Ireland.

In this latter regard Petty's bold idea of 'transmutation' - the large-scale transplantation and inter-marriage of the English and Irish, in order to breed out cultural differences, reverse the imbalance of Protestant to Catholic population, and thus neutralise ideological conflict - dominates the scholarship in relation to The Political Anatomy, but he also concerned himself with the more immediately tractable idea of legislative union. Petty outlined what he saw as the 'Absurdities' and the 
'Inconveniences of the not-Union'. ${ }^{69}$ Union, for Petty, would clarify the status of Ireland in relation to England and, in theory, prevent resentment on all sides. For instance, it was illogical for Ireland to have its own legislature yet the final court for appeals reside in Westminster; this could only lead to confusion and dissatisfaction on both sides. ${ }^{70}$ Furthermore, Petty objected that the current trading arrangements between the two separate kingdoms required ships bound for Ireland had to unload first in England and then reship to Ireland, causing delays, risks to goods, and extra cost. ${ }^{71} \mathrm{He}$ argued that, because ports in Ireland were geographically well placed for trade with the colonies, the protectionist strictures of the 1660 Navigation Act, established to protect English trade, could be freed up for mutual benefit under a union. $^{72}$

Here The Political Anatomy connects with David Hayton's worries, mentioned earlier, over how discourse relating to union has been understood. ${ }^{73}$ Hayton locates the union sentiment largely with the English who had direct interests in Ireland, or with Irish absentees, such as Southwell (i.e. those who were not, as Hayton puts it, representative of the 'Irish political nation'). ${ }^{74}$ Instead of regarding The Political Anatomy as a counter in the revisionist debate, recapturing the role it was made to

\footnotetext{
${ }^{69}$ Petty, Political Anatomy, p. 31.

${ }^{70}$ Ibid., p. 32.

${ }^{71}$ Ibid., p. 33.

${ }^{72}$ Ibid., p. 79.

${ }^{73}$ Hayton, 'Ideas of Union in Anglo-Irish Political Discourse, 1692-1720: Meaning and Use', in Boyce, Eccleshall and Geoghegan, eds., Political Discourse, pp. 144. 1. Charles Ivar Mcgrath also questions how union discourse has been read in, 'The Union' Representation of 1703 in the Irish House of Commons', pp. 11-35.

${ }^{74}$ Hayton, 'Ideas of Union in Anglo-Irish Political Discourse', p. 146.
} 
play in post-1691 Ireland by examining the contexts of its production widens the range of the union discourse, further clarifies its purposes and tactics, and demonstrates how senior government figures understood the potential impact of print for political influence. In fact Petty's work spoke very personally for Southwell as The Political Anatomy defended absentee landlords as part of a union. ${ }^{75}$ Petty had no problem with Irish rents moving to England, a position that suited Southwell, who enjoyed his income from Kinsale whilst living in London or Kings Western. ${ }^{76}$ If there were union, Petty had argued, rents shifting from one part of that union to another, rather than from one kingdom to another, should nullify dispute and discontent.

Furthermore, The Political Anatomy's contents as a whole are worth consideration as they help bring out the purpose behind its publication, offering suggestions for Southwell's motives and also its contemporary reception. In addition to Tate's dedication to Ormond, following the text of 'The Political Anatomy' are Petty's 'Report from the Council of Trade in Ireland' (1676) and 'Verbum Sapienti' (1667). ${ }^{77}$ There is also some non-Petty material from the early $1660 \mathrm{~s}$; a copy of the commission from Charles II to instate the First Duke of Ormond as Lord Lieutenant of Ireland in February 1662, and a 1662 'Account of the Establishment of the Civil and Military List' in Ireland ('faithfully and carefully taken out of Authentick Records' Tate informs the reader ${ }^{78}$ ).

\footnotetext{
${ }^{75}$ Petty, The Political Anatomy, pp. 84-5.

${ }^{76}$ Ibid., p. 85.

${ }^{77}$ Thomas E. Jordan mentions the 'Report from the Council of Trade in Ireland' and 'Verbum Sapienti' in his A Copper Farthing: Sir William Petty and his Times 1623-1687 (Houghton-le-Spring: University of Sunderland Press, 2007), pp. 157, 165-7.

${ }^{78}$ Petty, The Political Anatomy, A6 ${ }^{\mathrm{r}}$.
} 
Petty's 'Report from the Council of Trade in Ireland' explored the union issue further (with the bigger idea of 'transmutation' absent), arguing that union would increase the revenue from trade for both kingdoms. A union had the potential to free up commerce from delay, extra risk to goods, and customs. ${ }^{79}$ Southwell stood to be a gainer from such freedom, and his hopes and fears for the Kinsale's revenue were often a subject of his correspondence with Petty. ${ }^{80}$

Moreover, the inclusion of the non-Petty material can be seen in the light of Southwell's concerns over Ireland's post-1691 land settlement and his connection to the Ormond family. The abbreviated title is commonly used when referring to this book, but the title page signals the publication's wider scope: The Political Anatomy of Ireland, with the establishment for that Kingdom when the Late Duke of Ormond was Lord Lieutenant. Taken from the Records. The inclusion of the Duke's commission in February 1662, and authority as Lord Lieutenant, directly recalls the earlier Restoration land settlement. ${ }^{81}$

We have already seen that in December 1691 Southwell was telling William King that 'all men are discoursing how to restore Ireland again to the settlement it had, or to a better' and land settlement was a long-standing concern for Southwell and Petty; it is a feature of their 1680 s correspondence. They had lived through two

\footnotetext{
${ }^{79}$ Ibid., p 125.

${ }^{80}$ See the Petty-Southwell Correspondence, ed. by Landsdowne, Southwell to Petty, from Kings Western, 11 September 1682, p. 101 (letter 56), 14 February 1687, p. 255 (letter 149), 3 November 1686, p. 238 (letter 136), 21 May 1687, pp. 269-270 (letter 160).

${ }^{81}$ For the first Duke of Ormond see J. C. Beckett, The Cavalier Duke: A Life of James Butler, First Duke of Ormond, 1610-1688 (Belfast: Pretani Press, 1990), Raymond Gillespie, 'The Religion of the
} First Duke of Ormond' and G. E. Aylmer, 'The First Duke of Ormond as Patron and Administrator', in The Dukes of Ormond, ed. by Barnard and Fenlon, pp. 101-13 and pp. 115-35. 
periods following a change of monarch where their Irish property was in question, firstly after the Restoration in $1662-3,{ }^{82}$ and between $1685-89$, during James II's reign, ${ }^{83}$ and The Political Anatomy should be seen as Southwell's response to a third. Southwell, in possession of Petty's papers, with access to official records, and with his friend's memory in mind, recalled the events of 1662-3 and used them in this carefully-edited, printed book for political influence. Furthermore, he did so in such a way as to make the 1662 material, along with Petty's 'Report' of 1676 appear of a piece with 'The Political Anatomy' itself. In the prefatory material Tate writes

P. 114. begins the famous Report from the Council of Trade in Ireland, which was not only Drawn, but wholly Composed by Sir William Petty; and with which that Council concurred unanimously.

P. 132. followeth the Copy of the Commission of the late Duke of Ormond to be Lord Lieutenant; and an Account of the Establishment of the Civil and Military List in his time; faithfully and carefully taken out of

\footnotetext{
${ }^{82}$ This was in relation to the Restoration Act of Settlement (1662), the Court of Claims (1663) and their consequences; Landsdowne, ed., Petty-Southwell Correspondence, Southwell to Petty, from Kings Western, 14 October 1682, p. 108 (letter 60). For the context see, L. J. Arnold, 'The Irish Court of Claims of 1663', Irish Historical Studies, 24 (1985), 417-30, Karl S. Bottigheimer, 'The Restoration Land Settlement in Ireland: A Structural View', Irish Historical Studies, 18 (1972), 1-21, Coleman A. Dennehy, 'The Restoration Irish Parliament', in Restoration Ireland, ed. by Dennehy, pp. 53-68, and Jane Ohlmeyer, Making Ireland English (New Haven and London, Yale University Press, 2012), Chapter 11, 'The Restoration Land Settlement', pp. 301-35.

${ }^{83}$ Landsdowne, ed., Petty-Southwell Correspondence, Southwell to Petty, from Kings Western, 25 August 1685, p. 140 (letter 80), Petty to Southwell, from Piccadilly, 1 September 1686, p. 234 (letter 132), Southwell to Petty, from Kings Western, 4 October 1686, p. 235 (letter 133).
} 
Authentick Records; And to the Nature of which, the continued Title of The Political Anatomy of Ireland, on those passages, agrees well enough. ${ }^{84}$

Accordingly, the table of contents lists these two documents under the title of 'The Political Anatomy' (see figure 1) and appear under this running title throughout as well. The title entered in the Stationers' Register groups this material together similarly as 'The Political Anatomy of Ireland 1672, with a treatise enjoyned Entitled, Verbum Sapienti' ${ }^{85}$ It is unlikely that Tate took this level of initiative with the publication and the most plausible inference must be Southwell's guiding hand. Perhaps Petty's report 'agrees well enough', but the 1662 material only fully agrees when seen from Southwell's perspective, what he understood 'The Political Anatomy' to be about, his shared history of settlement perturbations with its author, and his fresh concerns in 1691.

Petty's 'Verbum Sapienti' might seem to be an outlier in this book, as an economic anatomy relating to England and Wales but, seen in the context of Southwell's general editorship, this part of the book is also folded into the union debate. In taking financial stock of England and Wales here, the relative wealth of, and the economic relationship between, the two kingdoms (and by implication the political relationship) are put on a clear footing. Antoin E. Murphy regards 'Verbum Sapienti' as Petty's 'greatest contribution' to economic thought in his longitudinal history of macroeconomics. He also writes that is was 'Published posthumously in 1691, alongside the Political Anatomy of Ireland, [and] it looks as if it was tacked onto the latter work almost as an afterthought [...]. The editor was unable to see the

\footnotetext{
${ }^{84}$ Petty, The Political Anatomy, A6 ${ }^{\mathrm{r}}$.

${ }^{85}$ Transcript of the Registers, 3, p. 386.
} 
sheer brilliance of this work. ${ }^{86}$ Again the hand of 'posthumously' is steering here, and an assumption of implied editorial looseness governing the practices of print culture lies underneath this argument. Yet there was too much at stake for 'tacked on' material and 'afterthoughts' in early $1691 .^{87}$ We know Southwell understood the brilliance of Petty's work, and perhaps Nahum Tate came to understand it too, but its brilliance was carefully edited here and harnessed to 1691 Ireland.

In 1691, given what we know about Southwell's activities and given the publication circumstances - with Tate as editor, his additional dedicatory matter to Ormond, Petty's 'Report', 'Verbum Sapienti', as well as the non-Petty material from the early 1660s - The Political Anatomy as a printed book looks like a multi-angled anthology engaging in debates over trade, union, governance and land settlement in 1691. Southwell considered Petty a remarkable man and he attempted to pitch what he saw as credible and intellectually heavyweight arguments into this debate and, although this publication re-locates Petty's work, Southwell and Petty's long, common history and anxiety over their interests in Ireland demonstrate a close consonance in their ideas and political aims.

After Petty's death Southwell was solicitous to honour his friend's legacy: 'I ever thought' he promised Petty's widow 'for almost 26 yeares past that Sir William Petty was in severall respects the greatest amongst mortals that I ever saw, and the world can never sufficiently deplore his losse [...]. I will pay to his memory all the

\footnotetext{
${ }^{86}$ Antoin E. Murphy, The Genesis of Macroeconomics: New Ideas from Sir William Petty to Henry Thornton (Oxford: Oxford University Press, 2009), p. 30.

${ }^{87}$ Moreover, considering this from a cost point of view, 'Verbum Sapienti' covers just over 1.5 sheets of paper. As printed books were a considerable investment, and paper the most expensive resource, randomly 'tacking on' material would not make much business sense.
} 
service I am able ${ }^{88}$ It is not a straightforward matter to suggest that Southwell's actions in publishing The Political Anatomy represent a distortion of Petty's intentions. Southwell was a broker for Petty, in this case over time, rather than geographical distance in relation to William King. His own interest in putting the manuscript to immediate personal and political use in 1691 coincided with much of what Petty had believed, and this ran alongside Southwell's desire, as stated to Elizabeth Petty, to honour her husband's brilliance more publicly and for posterity. In fact, for Southwell, honouring Petty's legacy in print was as much about putting his work to tangible political use in settling Ireland as they both would have wished, as it was about erecting a monument to his scientific intellect.

\section{Conclusion}

Southwell's activities between late 1690 to early 1692, particularly the nature of his little-known engagements with print culture at this time, shows how sensitively senior figures close to Whitehall could use printed books as tools for political argument and how nuanced their understanding of their impact on different kinds of reader could be. Care should be taken in assuming that print brought into being McCormick's 'faceless reading public' particularly in late seventeenth-century London and with the highly topical kind of publication this article has considered. The circulation to specific people at different stages of drafting and the attention paid to The State of the Protestants' possible reception as it went quickly through several printed editions demonstrate that readers of King's work in 1691 had recognisable faces and a

\footnotetext{
${ }^{88}$ Petty-Southwell Correspondence, ed. by Landsdowne, Southwell to Elizabeth Petty, from Kings Western, 23 December 1687, p. 333 (letter 93).
} 
coterie/mass market assumption underlying the distinction between manuscript and print cultures needs qualification. Europe's Deliverance passed through many hands, personally delivered on the author's behalf as gifts, ultimately reaching the Queen. The closely-engaged network of friends and allies operated in London on King's behalf using printed books in order to bring his argument to those in power.

The revisionist historians' close attention to Petty's legacy has placed too much emphasis on manuscript/print and living/posthumous distinctions. These, when further mapped onto a pre-/post-1688 revolution distinction - where 'the revolution of $1688[\ldots]$ swept away both the political circumstances and many of the people that [Petty's] manuscript proposals had addressed' - produce a neatness that a close look at The Political Anatomy in 1691 complicates. ${ }^{89}$ There are important continuities to keep in mind as well as changes brought in by the revolutionary turbulence. It certainly was the case that, at a later date, Petty's ideas, shorn of their context, were made to fit a narrative of economic history and a view of scientific method that misrepresents them. Yet Southwell's editorial role in The Political Anatomy should not be seen as the beginning of this distortion and become ravelled up in that argument over the posthumous legacy. This article demonstrates that The Political Anatomy in 1691 was a targeted political intervention, certainly one consonant with Southwell's interests, but not straightforwardly a distortion of Petty's intentions, and not without his consent. Furthermore, their correspondence shows Petty became concerned for his legacy and recognised that printed books - under Southwell's stewardship - were the means to securing it.

\footnotetext{
${ }^{89}$ McCormick, William Petty, p. 287
} 
In attending to David Hayton's concerns over the impressionistic analysis of Anglo-Irish political discourse, particularly unionist discourse, this article has argued it should be put under the closest scrutiny, including its material culture. Such scrutiny might reconfigure how we approach King's ideas of Ireland and England when The State of the Protestants was written and printed. Christopher Fauske argues King's book demonstrates 'that Ireland was a free sovereign state' and 'Ireland is [...] clearly identified by King as a separate kingdom from England' ${ }^{90}$ Fauske's reading sees King's later patriotism established quite early and definitely after the Jacobite wars, whereas Patrick McNally draws the opposite conclusion from The State of the Protestants noting that 'King's [...] comments on the Anglo-Irish relationship [...] appear to emphasise Ireland's dependent status' and he sees 'a degree of dependence on the part of Ireland to which Irish protestants would not always adhere in the future'. ${ }^{91}$ As we have seen Southwell, one of the book's most powerful advocates, had a keen interest in union, and the Secretary of State, Daniel Finch, who agreed the book's license, did not favour Irish independence. The reception context highlights that some very interested and powerful readers saw no obvious case for independence in The State of the Protestants, and this in turn might tip the scales towards McNally's view. Yet, at the very least, it shows that arguing determinately about essential meanings is difficult, especially in a febrile, politically-charged reception climate.

Other reception contexts, such as readers' marginal annotations can also suggest directions. One early eighteenth-century reader of King's Europe's Deliverance, concerned about Jacobitism and matters of Irish independence,

\footnotetext{
${ }^{90}$ Fauske, William King: A Political Biography, pp. 81, 79.

${ }^{91}$ Patrick McNally, 'William King, patriotism and the 'national question', in Archbishop William King and the Anglican Irish Context, ed. by Fauske, pp. 47-72 (p. 51).
} 
underscored King's claim that James II's plan to introduce a military force of 150,000 men in Ireland was in order to make them 'Instruments of [...] slavery'. He particularly highlighted the further worry that 'Ireland was to be separated from the Crown of England, and made independent on it. ${ }^{, 92}$ He also recommended The State of the Protestants for further reading (referring to it as 'the late excellent book' by this 'worthy author'), and then suggested the following publications: 'the Rebellion and Massacre in Ireland $23^{\text {th }}$ of October 1641 by $S^{\mathrm{r}}$ John Temple [...] and Doct ${ }^{\mathrm{r}}$ Burlace

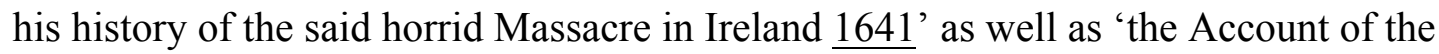
many Secret Consults and designs for the Entroducing of popery in Ireland from the year 1660 to $\mathrm{y}^{\mathrm{e}}$ year $16899^{93}$ Scholarship has shown that King showed more moderation towards Catholics than Presbyterians in Ireland, yet this reader framed King within an extreme discourse of 1641 Catholic atrocities (particularly John Temple's book) and on-going history of popish secrecy and subversion. ${ }^{94}$ Moreover, this reader's concern over Irish independence, and his interpretation of King's November 1690 sermon and The State of the Protestants, was not consonant with King's early eighteenth-century political stance and Irish patriotism at the time these marginal notes were made.

\footnotetext{
${ }^{92}$ King, Europe's Deliverance, London, British Library, shelfmark 226.g.15.(19)., p. 12.

${ }^{93}$ Ibid., A2 ${ }^{\mathrm{v}}$ and $\mathrm{A} 3^{\mathrm{v}}$. The titles refer to John Temple's The Irish Rebellion: or, An History of the Beginnings and First Progresse of the General Rebellion raised within the Kingdom of Ireland, upon the Three and Twentieth Day of October, in the Year, 1641 (London: Samuel Gellibrand, 1646), Edmund Borlase's The History of the Execrable Irish Rebellion (London: Richard Chiswell, 1680), and the anonymous, A Full and Impartial Account of all the Secret Consults, Negotiations, Stratagems, and Intriegues of the Romish Party in Ireland, from 1660, to this Present Year 1689, for the Settlement of Popery in that Kingdom (London: Richard Chiswell, 1689).

${ }^{94}$ McNally, 'William King', pp. 53-5.
} 
An indignant reader in 1829 engaged with Petty in the margins of his 1691 copy of The Political Anatomy. In response to Petty's defence of rents leaving Ireland for England (part of his argument for union) ${ }^{95}$ the annotator wrote, ' $\mathrm{Oh}$ - confound you! What a Fool this Man makes of himself - if the rents are spent within the Country the Money will enrich the whole - but spent out of it - the Money never returns' ${ }^{96}$ In discussing the problems caused by two legislative bodies Petty wrote (again to justify union) ${ }^{97}$ 'It is absurd, that English-men in Ireland should either be Aliens there, or else to be bound by Laws, in the making whereof they are not represented'. The marginal response states 'Witness the English Act which shut out Ireland from trading with the Collonies [...] XX Charles $2^{\mathrm{d}},{ }^{98}$ The 1660 Navigation Act, passed by the Westminster parliament, had prevented Ireland from exporting to the colonies, thus protecting trading interests in England and damaging Ireland's. By suggesting the injustice for Ireland of being bound by Westminster and the Navigation Act the annotator was implicitly supporting independence (whereas Petty, contrarily, had argued against this Act in order to advocate union). As we have seen, Karl Marx also consulted this 1691 edition for his Capital, helping frame Petty's nineteenth-century legacy in terms of political economy, yet the book's argument in terms of Irish politics, for this annotator at least, was clearly still a live one.

The argument here has centred upon Sir Robert Southwell, William King, and Sir William Petty - whilst also revealing the function of less visible figures (George Tollet, Robert Clavell, and Nahum Tate) - as representatives of broader Protestant

\footnotetext{
${ }^{95}$ Above, p. 33.

${ }^{96}$ Petty, The Political Anatomy, London, British Library, shelfmark 8145.aa.21., p. 85.

${ }^{97}$ Above, p. 32

${ }^{98}$ Petty, The Political Anatomy, London, British Library, shelfmark 8145.aa.21., p. 32.
} 
Anglo-Irish anxieties over the political future, and Southwell and King's personal futures, in post-war Ireland and London. Although Southwell was never especially visible or high-ranking in political circles he was energetic, ambitious and often had great influence. Winnowing out from his extensive correspondence why, how, and with whom he collaborated in order to wield that influence throws new light on the workings of political discourse and the increasing importance of print for political culture, and a growing sophistication in its use, in late seventeenth-century Ireland and England. 
ADVERTISEMENT.

P. 1 I4. begins the famous Report from the Conncil of Trade in Ireland, which was not only Draipn, but wholly Compofed by Sir William Petsy; and with which that Sir' William Petry; and with whe
Council concurred unanimoufly.

$P .132$. followeth the Copy of the Consmifion of the late Duke of Ormond to be Lord Lieutenant ; and an Account of the Eftablijs:ment of the Civil and Military Lift in his time; faith fully and carefully taken in his time; of the Civil and Milirary Lift the Nature of which, the continued Title of 'The Political Anatomy of Ireland, on thofe $P_{a}$. ges, agrees well enough.

'The Volume concludes with Sir William pettys Verbum Sapienti, which relates wholly to England, and fhews how Taxes may be cqually laid, and how the Nation may well bear the Tax of Four Millions per

Annum.

The Reader is now left with his moft Critical attentive Judgment, to enjoy the benefit of the great Political knowledg that Sir William Petty hath taught the Age; and for which (as one of the greateft Orna ments of it) he deferveth perpetual celebrations. Know Reader in a word, That

Nulla forent talcm Secla futura virum. The;

The Contents.

of the Trade of Ireland, and its Impediments; the Commoditics, and aptitude for Traffick, and incidently of the Cloaths and Dyet of the Pcople: Of Sumptuary Dyet of the Pcople: Of Sumptuary Laws, Abfentecs, Qc.
75
of the Religion, Language, Manners, and Of the Religion, Language, Manners, and
Intereft of the prefent Inhabitants of Ireland; as. alfo of the Prefint and Ancicat Divifions and Names of the Lands, 93

Some Mifcellany Remargues and Intimations concerning Ireland, and the feveral mat. concerning Ireland, and the Jeveral mat.
ters aforementioned, ters aforementioned,
Report from the Conncil of Trads in IreA Report from the Conncil of Trade in Ire-
land, totbe Lord Lieutenant and Council, \&c.

Confiderations relating to the 1 mprovement of$$
\text { Ireland, }
$$

Inferences from the Premifes,

I20

Propofitions to His Majefty concerning the

Government of Ireland, 146 The Lift for Civil Affairs, \&c.

The Eftablifbment and Lift, containing all the

Payments to be isade for Military Affairs,

$$
\text { \&c." }
$$

Officers Provincial,

Conftables,

Swndry Minifters belonging to the Ordmance,

viz. in Lemfter,

The CONTENTS of the Political Anatomy of IREL.AND.

O the Lands of Ireland, with the pre-
fent diftribution and Valses of the Page $\mathbf{x}$
of the People, Honses and Smokes; their Nimber, Differences and Values, Of the Church and Benefices,

Concerning the late Rebellion and its effects 16 Of the future Settlement of Irind Pre 7 tion of Rebellions, and its Union wit's Eng-

of the Government of Ireland, Apparent 25 Internal.
Of Of the Militin and Defence of Ircland, 32 of the Coxlum, Solum, \& Hrures; or the Air, Soil and Product of Ircland or the of the Rate which the Lands in Ireland $d_{0}$ bear to eachother, with the Hiftory of the feveral Valuations of the fome, 58 of the Mosey of. Ireland, and the Causes of its Decreale, with the Remedy for the
fame,

9

Connaiught,

Munftcr,

Uilfer,

Temporary Payment

$A$ Catalogice of the Pecrs,

Lift of the Arch:Bißjopricks and Bißbop-

ricks,

The Contents.

A Lift of those Places that return Parliament-

Men, \&c.

202

Verbum Sapienti.

Ntroduction,

Chap.1. Cont aining feveralC Page 1

of the Wealth of the King computations

Chap. 2. Of the $V$ the Kingdom,

Chap. 2. Of the Value of the People,

Chap. 3. Of the Jeveral Expences of the

Kingdom, and its Revenue,

Chap. 4. Of the Method of apportioning Taxes,

Chap. 5. Of Money, and how much is necef-

Chap. 5. Of Money, and how much is nece-
fary to drive the Trade of the Nation,

Cary to drive the Trade of the Nation, I
Chap. 6. The Caufes of Irregular Taxing, I

Chap. 6. The Caules of Irregular Taxing, 5
Taxes, The Collateral Advantages of the 5 ,

Chap.

Cons

Figure 1: Contents pages showing Southwell's integration of other material into the body of The Political Anatomy (1691), A6 ${ }^{\mathrm{r}}-\mathrm{A} 7^{\mathrm{r}}$. 